\title{
THE INFLUENCE OF MACROECONOMIC CONDITIONS ON CREDIT RISK: CASE OF ROMANIAN BANKING SYSTEM
}

\author{
Iulia Andreea Bucur \\ "Vasile Alecsandri" University of Bacău \\ iuliaandreea.bucur@gmail.com \\ Simona Elena Dragomirescu \\ "Vasile Alecsandri" University of Bacău \\ dragomirescu@ub.ro
}

\begin{abstract}
This paper aims to explore the interactions between macroeconomic conditions, such as: real GDP growth rate, inflation rate, market interest rate, broad money supply, foreign exchange rate fluctuation and unemployment rate, and credit risk in Romanian banking sector during 2008-2013. The interrelations of indicators' complexity imply a multidimensional statistical analysis in order to find a relation between the macroeconomic conditions and the credit risk. Our regression analysis findings confirm the hypothesis according to which the money supply growth rate and the market foreign exchange rate are negatively related with credit risk and the unemployment rate is positively related with it. Furthermore, our findings revealed that the credit risk is significantly and negatively affected by the exchange rate fluctuation and significantly and positively affected by the unemployment rate. The results do not indicate a significant relationship between credit risk and real GDP growth rate.
\end{abstract}

\section{Keywords}

credit risk; non-performing loans; Romanian banking system; macroeconomic determinants

\section{JEL Classification}

E44; E51; G21; F41

\section{Introduction}

Nowadays, a highly significant role, even vital, in an economy is played by the financial institutions. The stability of the financial system is the basis of the modern macroeconomic policy and, at the same time, a prerequisite for strong economic growth (Rajaraman \& Vasishtha, 2002; Kroszner, 2007) and welfare (Kristo, 2013), which ensure macroeconomic stability and enable strong financial institutions (Bairamli \& Kostoglou, 2010).

Risk takes many forms, each affecting the economic activity on a lesser or greater extent (Solomon \& Muntean, 2012). The recent international crisis stressed the magnitude that financial institutions vulnerabilities can have on the economy in the frame of monitoring and managing credit risk (Agnello, Furceri et al, 2011; Vogiazas \& Nikolaidou, 2011). One of the areas of risk management, Credit Risk Management is fundamental for minimizing credit loss (Santomero, 1997), therefore the financial institutions develop their own models in order to decrease credit risk (Poudel, 2013). This risk often reaches high levels that affect individual commercial banks, the financial system and also the economy as whole (de Guimaraes e Souza \& Feijo, 2011).

Moreover, due to the fact that, among various risk in a bank, credit risk depends on the bank asset quality and the primary cause of bank failures (Gup \& Kolari, 2005; Bhattacharya \& Roy, 2008; Samad, 2012), it is crucial to identify the drivers of the 
credit risk, especially macroeconomic ones, that are considered to play a significant role on this matter (Demirguc-Kunt \& Detragiache, 1998; Llewellyn, 2002), and may affect the stability of the banking system and also to quantify their influence.

In the context of the turmoil in international financial market caused by the global crisis and of the risk aversion of banks and given that the Romanian banking system is dominated by foreign-owned commercial banks, since the second half of 2008, the lending process is restricted considerably, especially in retail, credit became less accessible and more expensive and the deposit rate is reduced. Also, the deterioration loan portfolio quality, mainly due to rising unemployment and to the high level of interest rate, increases the vulnerability of the Romanian banking system. However, banks have sufficient own resources to cover any unexpected losses from credit risk remained uncovered by the provisions made and realization of collateral to the borrowers (Bucur, 2013).

Factors such as unemployment and uncertainties in the labor market, reduced income, restricted exports, diminishing FDIs, decrease in the market value of land and buildings affect the performance of credit institution (NBR Annual Report, 2009). Romanian banking sector, with levels of capitalization, solvency and liquidity consistent with prudential requirements (NBR Annual Report, 2010), absorbed the shock of crisis fairly well, but with the price of a more reduced performance, of the risk associated with particular emphasis on the dynamics and persistence of Nonperforming loans (NPLs), of prolonged inhibition of credit demand and of a relatively high dependence of external financing. In 2011 and also in 2012, commercial banks operating in Romania had to face with deteriorating economic potential and foreign exchange market developments, with the increasing of the credit risk ratio and of nonperforming loans and also with the gradual implementation of the new Basel III requirements (NBR Annual Reports, 2011, 2012). In 2013 the appropriate level of the main prudential indicators allowed the banking sector to face with major difficulties increasing NPLs ratio (Figure 1) and also with the necessity of optimizing the loan portfolios to prepare the implementation of Basel III. Thus, the banks focused more on the non-performing exposure management solutions and less on the resumption of lending process in terms of the sustainability (NBR Annual Report, 2013).

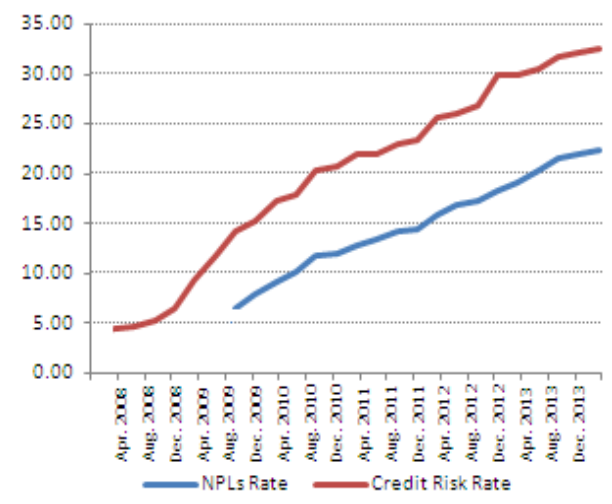

\section{Figure 1 Trend of NPLs Rate and Credit Risk Ratio in Romania, 2008-2013}

Source: Own calculations, based on the data available on NBR

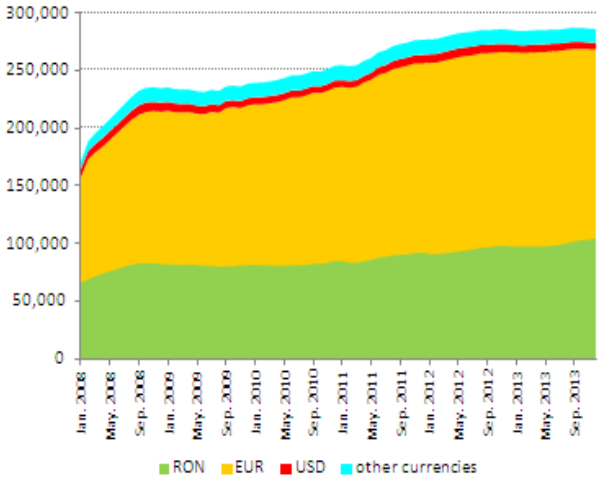

Figure 2 Proportion of national and foreign currency lending in Romania, 2008-2013

Source: Own calculations, based on the data available on NBR

Moreover, the high proportion of foreign currency lending (Figure 2), especially euro, mainly to households elevates the credit risk profile of the Romanian banking 
institutions while the stressed liquidity reflected in credit to deposit ratio may lead to a tighter credit supply (Vogiazas \& Nikolaidou, 2011).

In our study, based on the aggregate available data on National Bank of Romania (NBR) and Eurostat, we explore the links between credit risk ratio in Romanian banking sector and macroeconomic determinants, such as: economic and business cycle, inflation, market interest rate, money supply and exchange fluctuation, unemployment, during the period of time 2008-2013. Given the complexity of the macroeconomic indicators, a statistical analysis was performed in order to find a relation between the macroeconomic conditions and the credit risk ratio.

Our regression analysis findings confirm the hypothesis according to which the money supply growth rate and the market foreign exchange rate are negatively related with credit risk and the unemployment rate is positively related with it. Furthermore, our findings revealed that the credit risk is significantly and negatively affected by the exchange rate fluctuation and significantly and positively affected by the unemployment rate. Our results do not indicate a significant relationship between credit risk ratio and real GDP growth rate.

The paper is structured as follows. Section 2 reviews the theoretical framework regarding the issue of macroeconomic determinants of credit risk. Data and methodology of the study are presented in Section 3, followed in Section 4 by the empirical analysis completed by explaining the influence of independent variables on the credit risk ratio as dependent variable. Section 5 contains a brief summary of our research and the concluded remarks driven by the results obtained and their interpretation.

\section{Literature review}

Due to the fact that the availability of published data regarding banking sector increased significantly, many researchers have begun to turn their attention on loan portfolio quality. Some of them consider NPLs as "financial pollution" with harmful effects for economic growth and welfare as well (Gonzales-Hermosillo, 1999; Barseghyan, 2010; Zeng, 2011). Moreover, the studies show that country-specific credit risk determinants have become more important for the emerging economies in the recent period of globalization and less important for industrial economies (Mileris, 2012b).

Without neglecting the effects of microeconomic (banking-sector) factors on the NPLs (credit to total deposit ratio, capital adequacy ratio, return on asset and return on equity, net interest margins, net income, interbank loans), in the light of the empirical literature reviewed, the analysis of the factors that influence the loan portfolio quality is based on the hypothesis that banks' credit risk is sensitive to macroeconomic environment, such as: business cycle, price stability, broad money supply, market interest, foreign exchange fluctuation and even unemployment. The literature mentions a diversity of macroeconomic factors, both internal and external (Sinkey \& Greenawlat, 1991) that play a significant impact on loan quality.

Important changes in the macroeconomic conditions of a country are observed in both economic and business cycle. It has been ascertained that banks becomes vulnerable and credit risk increases during the stagnation and recession period than during the economic growth one (Hardy \& Pazarbasioglu, 1998) and also due to an increasing level of aggregated indebtedness (Fainstein \& Novikov, 2011).

Thus, whereas some researchers found in their studies a negative relationship between Gross Domestic Product (GDP) and credit risk (Salas \& Saurina, 2002; Jimenez \& Saurina, 2006; Das \& Ghosh, 2007; Gunsel, 2012; Louzis, Vouldis \& Metaxas (2012); Thiagarajan, Auuapan et al, 2011; Zribi \& Boujelbene, 2011; Castro, 2013), while others found no relationship between real GDP growth rate and loan portfolio 
quality in case of Austrian banking system (Kalirai \& Scheicher, 2002), of SubSaharan Africa banking system (Fofack, 2005), in case Slovenian banking system Aver (2008) or, more recently, in case of Nepalese banking industry (Poudel, 2013).

Inflation also affects the performance of the banking sector. A rise in inflation in the context of cyclical downturns negatively affects the efficiency of the banking sector, whereas the hyper-inflation may affect the assets and equity of banks (Fofack, 2005). There are authors that suggest that the influence of the inflation rate on the profitability of the financial institutions depends on whether the expenses increase faster than inflation (Athanasoglou \& Brissimis et al, 2008). A positive relationship between inflation and credit risk was identified by some authors in North Cyprus (Gunsel, 2012) and Euro area member states (Rinaldi \& Sanchis-Arellano, 2006). On the contrary, other researchers identified a negative relation between inflation and NPLs in case of Hong Kong banking system (Shu, 2002), of Tusian banking system (Zribi \& Boujelbene, 2011), of Romanian banking system (Vogiazas \& Nikolaidou, 2011), or in case of Solvenian banking system (Aver, 2008; Bofondi \& Ropele, 2011; Castro, 2013) or Nepalese banking industry (Poudel, 2013). In his research, Fofack (2005) found that inflation is not significant in explaining the dynamics of NPLs loans, especially for African Financial Community (CFA) countries. Also Valahzaghard et al (2012) found no significant relationship between inflation rate and credit risk in Iran.

The economic growth can be positive influenced by the accelerating board money supply (Berk \& Bikker, 1995). Thus, considering that increasing money supply will decrease the interest rate and create the opportunity of cheaper funds and also the ability of debtors to honor their financial obligations and this will contribute to decreasing NPLs (Ahmad \& Ariff, 2007). The influence of board money supply growth rate on credit risk was analyzed by some authors that found a negative relationship between the considered variables in case of Malaysian banking system (Ahmad, 2003), in case of Austrian banking system (Kalirai \& Scheicher, 2002), in a case of Romanian banking system (Vogiazas \& Nikolaidou, 2011) or Nepalese banking system (Poudel, 2013). Instead, there are studies that revealed a positive relationship between money supply growth rate and credit risk for Italian banking system (Bofondi \& Ropele, 2011), or for CFA countries (Fofack, 2005).

The real interest rate affects the debt burden, which means that its effect on the credit risk should be positive: increasing interest rates will lead to a higher NLPs ratio (Gonzalez-Hermosillo, 1997; Aver, 2008; Louzis, Vouldis \& Metaxas, 2012; Nkusu, 2011). Similar results, significant and positive relationship between credit risk and real effective interest rate, was found in case of Sub-Saharan Africa (Fofack, 2005), Italian banking sector (Quagliariello, 2007) and also in case of Greece, Ireland, Portugal, Spain and Italy (Castro, 2013). Instead, other studies do not identify any relevant correlation between interest rate and credit risk, as in Australia (Ali \& Daly, 2010).

One of the main determinants of economic instability is the exchange rate volatility (Zameer \& Siddiqi, 2010). The appreciation of foreign currencies against the national one generates higher prices for imported inputs which affects the prices of the final goods. Thus, as a result of exchange rate depreciation, the demand for loans increases in order to support the additional expenditure (Ngerebo, 2011). Castro (2013) identified that real effective exchange rate is negative related with loan portfolio quality for Greece, Ireland, Portugal, Spain and Italy from 1997 to 2011, by Zribi \& Boujelbene (2011) for Tunisian banking system, by Gunsel (2012) for North Cyprus, by Vogiazas \& Nikolaidou (2011) for Bulgaria and also by Fofack (2005). Other studie have not identified any relationship between foreign exchange fluctuation and NLPs ratio, such as: Kalirai \& Scheicher (2002) for Austria and Aver (2008) for Slovenia. 
Measures of unemployment appear to be a good predictor of problem loans all countries (Gambera, 2000), so there are many studies that analyze the influence of the unemployment rate on the credit risk. Analyzing possible factors influencing Romanian bank asset quality, as well as the contagion effect of the Greek crisis, Nikolaidou \& Vogiazas (2013) found that along with money supply, loan growth and the Greek loan loss provisions, the unemployment influence loan portfolio quality significantly. Louzis, Vouldis \& Metaxas (2012) explored the Greek banking industry in pre-crisis period and discovered that the besides the impact of GDP growth rate and lending rates, unemployment have a strong negative influence on credit risk. Also Valahzaghard et al (2012) analyze the unemployment rate influence on loan portfolio quality in the banking system of Iran and their results indicate no significant relationship between unemployment rate and credit risk.

\section{Data and methodology of the study Data}

As mentioned before, the aim of our study is to identify the possible factors that influence aggregate credit risk in the Romanian banking system and to quantify their impact.

For our empirical research, we chose to collect macroeconomic aggregate data, in order to tackle possible problems of disaggregate data unavailability. Thus, based on the aggregate available data on National Bank of Romania (NBR) and Eurostat, we explore the links between annual credit risk ratio in Romanian banking sector and macroeconomic determinants, such as: annual real GDP growth rate, annual inflation rate, annual board money supply growth rate market, annual market interest rate, annual foreign exchange rate fluctuation and annual unemployment rate, during the period of time 2008-2013. We selected the variables taking into consideration the indicators presented and used in the previous research, for reasons of comparability of the results.

Te dependent variable, credit risk ratio, is calculated on the basis of prudential reporting into force on the classification of loans (are classified only the loans for which minimum capital requirements for credit risk are determined) (NBR Annual Report, 2013). In the interpretation of the NBR, credit risk for Romanian banking system is defined as the gross exposure related to nonbank loans and interest under "doubtful" and "loss" to total loans and interest classified related to nonbank loans excluding off-balance-sheet items.

\section{Methodology}

Given the interrelations of macroeconomic indicators complexity, a descriptive and a multidimensional statistical analysis was performed in order to find a relation between the macroeconomic conditions and the credit risk ratio.

The multiple regressions complete model is:

$$
y=\alpha+\beta \cdot x+\varepsilon
$$

Where: $\mathrm{y}$ is the dependent variable, representing the credit risk ratio, $\mathrm{x}$ is the independent variable, $\alpha$ is the constant parameter and $\varepsilon$ is the residual value.

Based on the empirical research, we test the following hypothesis: the real GDP growth rate, the broad money supply growth rate and the foreign exchange rate fluctuation are negatively related with credit risk, whereas the inflation rate, the market interest rate and the unemployment rate is positively related with credit risk. 


\section{Empirical analysis}

\section{Descriptive statistics}

The descriptive statistics for the dependent and independent variables (Table 1, Figures 3-4) indicates the deterioration of the loan portfolio quality in Romanian banking sector, credit risk ratio (CRR) ranging from a minimum value of 5.95\% registered in 2008 to a maximum one of $32.14 \%$ in 2013, with a mean value of $19.19 \%$, amid the wide range for real GDP growth rate (RGDPGR) of $13.90 \%$, for broad money supply growth rate (BMSGR) of $14.80 \%$ and for foreign exchange rate fluctuation (EXCHRF) of $15.90 \%$. The mean value for market interest rate (MINR) is $13.24 \%$ where the maximum level is $17.47 \%$ in 2008 and minimum one is $9.14 \%$ in 2013.

Also, the statistics indicates an average value for inflation rate (INFR) of $5.33 \%$, while its trend is a decreasing one, from the maximum value of $7.90 \%$ registered in the initial year of the considered period down to a the minimum value of $3.2 \%$ in the last year, 2013. In this context, we notice that the evolution of annual unemployment rate (UNEMR) was unfavorable; Romania registered a level of $5.80 \%$ in 2008 which increased up to $7.40 \%$ in 2012, fact that can affect the credit risk.

Table 1 Descriptive statistics of variables in the sample

\begin{tabular}{|c|c|c|c|c|c|c|c|c|}
\hline \multirow[b]{2}{*}{ Variable } & \multirow[b]{2}{*}{$\mathbf{N}$} & \multirow[b]{2}{*}{$\begin{array}{l}\text { Range } \\
(\%)\end{array}$} & \multirow{2}{*}{$\begin{array}{l}\text { Minimum } \\
\text { (\%) }\end{array}$} & \multirow[b]{2}{*}{$\begin{array}{c}\text { Maximum } \\
(\%)\end{array}$} & \multirow[b]{2}{*}{$\begin{array}{c}\text { Mean } \\
(\%)\end{array}$} & \multirow{2}{*}{$\begin{array}{c}\text { Std. } \\
\text { Deviation } \\
(\%)\end{array}$} & \multicolumn{2}{|c|}{ Skewness (\%) } \\
\hline & & & & & & & Statistic & $\begin{array}{l}\text { Std. } \\
\text { Error }\end{array}$ \\
\hline CRR & 6 & 26.19 & 5.95 & 32.14 & 19.19 & 8.94 & -0.101 & 0.845 \\
\hline RGDPGR & 6 & 13.90 & -6.60 & 7.30 & 1.00 & 4.69 & -0.525 & 0.845 \\
\hline INFR & 6 & 4.70 & 3.20 & 7.90 & 5.33 & 1.78 & 0.029 & 0.845 \\
\hline BMSGR & 6 & 14.80 & 2.69 & 17.49 & 8.59 & 4.92 & 1.236 & 0.845 \\
\hline MINTR & 6 & 8.33 & 9.14 & 17.47 & 13.24 & 3.18 & 0.351 & 0.845 \\
\hline EXCHRF & 6 & 15.90 & -0.80 & 15.10 & 4.97 & 6.54 & 0.806 & 0.845 \\
\hline UNEMR & 6 & 1.60 & 5.80 & 7.40 & 6.95 & 0.60 & -1.906 & 0.845 \\
\hline
\end{tabular}

Source: Own calculations based on the NBR and Eurostat available data

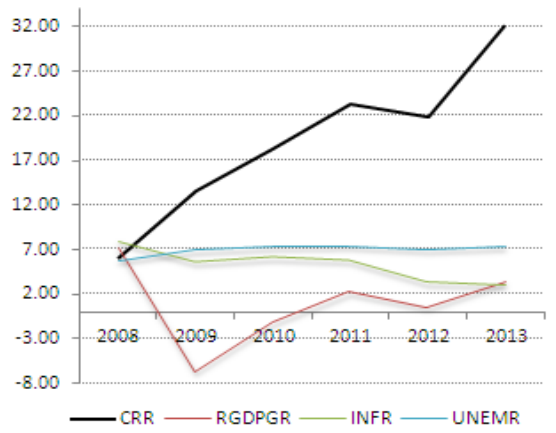

Figure 3 Trend of CRR comparing to GDP growth rate, inflation and unemployment in Romania, 2008-2013

Source: Own calculations, based on the data available on NBR and Eurostat

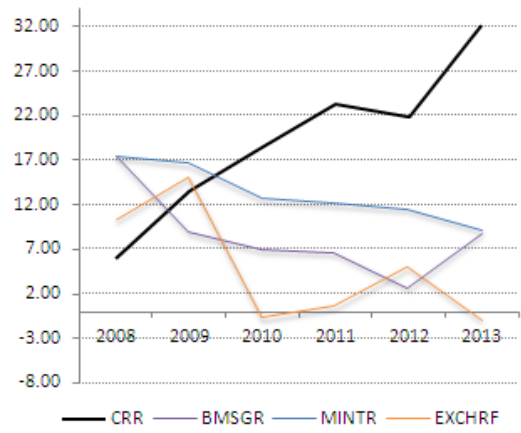

Figure 4 Trend of CRR comparing to money supply, interest rate and exchange rate in Romania, 2008-2013

Source: Own calculations, based on the data available on NBR and Eurostat 


\section{Econometric results}

In this unit we will test the hypothesis formulated before, using the same indicators for estimate the impact of the macroeconomic conditions on the credit risk in the Romanian banking sector, for the same period 2008-2013. The data base used in the regression analysis is process using the SPSS, in two steps: a univariate regression, in order to identify those conditions with the higher influence on the credit risk in Romanian banking system, and a multivariate model, in order to identify and estimate a cumulative impact of macroeconomic determinants on the credit risk.

In testing the hypotheses, both processes involve writing the equation for the model, estimating the parameters of the regression equation and interpreting the connection between the variables according to the sign and the value of the parameters for the regression model, as well as testing the significance of the regression parameters.

Due to the complexity of the phenomena, we analysed combined data using the correlation table from which we obtain information regarding the existence and direction of the relationships between the considered variables (Table 2).

Table 2 Correlations of variables in the sample

\begin{tabular}{|c|c|c|c|c|c|c|c|c|}
\hline & & CRR & RGDPGR & INFR & BMSGR & MINTR & EXCHRF & UNEMR \\
\hline \multirow{2}{*}{ CRR } & $\begin{array}{l}\text { Pearson } \\
\text { Correlation }\end{array}$ & 1 & -.010 & $-.845^{*}$ & -.636 & $-.963^{* *}$ & -.736 & $.816^{*}$ \\
\hline & Sig. (2-tailed) & & .985 & .034 & .175 & .002 & .095 & .048 \\
\hline \multirow{2}{*}{ RGDPGR } & $\begin{array}{l}\text { Pearson } \\
\text { Correlation }\end{array}$ & -.010 & 1 & .206 & .495 & -.115 & -.338 & -.441 \\
\hline & Sig. (2-tailed) & .985 & & .695 & .319 & .829 & .513 & .381 \\
\hline \multirow[t]{2}{*}{ INFR } & $\begin{array}{l}\text { Pearson } \\
\text { Correlation }\end{array}$ & $-.845^{*}$ & .206 & 1 & .727 & .810 & .382 & -.630 \\
\hline & Sig. (2-tailed) & .034 & .695 & & .102 & .051 & .454 & .180 \\
\hline \multirow[t]{2}{*}{ BMSGR } & $\begin{array}{l}\text { Pearson } \\
\text { Correlation }\end{array}$ & -.636 & .495 & .727 & 1 & .660 & .417 & $-.815^{*}$ \\
\hline & Sig. (2-tailed) & .175 & .319 & .102 & & .153 & .411 & .048 \\
\hline \multirow[t]{2}{*}{ MINTR } & $\begin{array}{l}\text { Pearson } \\
\text { Correlation }\end{array}$ & $-.963^{* *}$ & -.115 & .810 & .660 & 1 & $.847^{*}$ & -.768 \\
\hline & Sig. (2-tailed) & .002 & .829 & .051 & .153 & & .033 & .074 \\
\hline \multirow[t]{2}{*}{ EXCHRF } & $\begin{array}{l}\text { Pearson } \\
\text { Correlation }\end{array}$ & -.736 & -.338 & .382 & .417 & $.847^{*}$ & 1 & -.643 \\
\hline & Sig. (2-tailed) & .095 & .513 & .454 & .411 & .033 & & .168 \\
\hline \multirow[t]{2}{*}{ UNEMR } & $\begin{array}{l}\text { Pearson } \\
\text { Correlation }\end{array}$ & $.816^{*}$ & -.441 & -.630 & $-.815^{*}$ & -.768 & -.643 & 1 \\
\hline & Sig. (2-tailed) & .048 & .381 & .180 & .048 & .074 & .168 & \\
\hline
\end{tabular}

So we can identify a significant relationship between credit risk ratio and market interest rate $(-0.963)$, inflation rate $(-0.845)$ and unemployment rate $(0.816)$, a moderate relationship between the dependent variable and exchange rate fluctuation $(-0.736)$ and money supply growth rate as well (-0.963). A not significant relationship is indicated between credit risk ratio and real GDP growth rate $(-0.010)$. Regarding the direction of the relationship we can observe that all the considered independent variable, except unemployment rate, are negatively related with credit risk ratio.

The results of the regression analysis between the considered independent variables and the dependent one (Table 3) clearly indicate that, due to the value of $\mathrm{R}^{2}$, there is no significant relationship between the real GDP growth rate and credit risk in the Romanian banking system during 2008-2013 $\left(\mathrm{R}^{2}=0.000\right)$. 
Table 3 Results of the regression analysis between independent variables and credit risk ratio

\begin{tabular}{|c|c|c|c|c|c|c|c|}
\hline \multirow[b]{2}{*}{ NDEPENDENT VARIABLE } & \multicolumn{2}{|c|}{ MODEL } & \multicolumn{2}{|c|}{ ANOVA } & \multicolumn{3}{|c|}{ COEFFICIENTS } \\
\hline & $\begin{array}{c}\mathbf{R}^{2} \\
\text { (R Square) }\end{array}$ & $\begin{array}{l}\text { Std. Error } \\
\text { of the } \\
\text { Estimate }\end{array}$ & F Test & $\begin{array}{c}\text { F Test } \\
\text { Significance } \\
\text { (Sig.) }\end{array}$ & $\begin{array}{c}\text { Beta } \\
\text { Coefficient } \\
(\beta) \\
\end{array}$ & T Test $-\beta$ & $\begin{array}{c}\text { T Test } \\
\text { Significance } \\
\text { (Sig.) } \\
\end{array}$ \\
\hline RGDPGR & 0.000 & 9.99497 & 0.000 & 0.985 & -0.010 & -0.019 & 0.985 \\
\hline INFR & 0.714 & 5.34893 & 9.968 & 0.034 & -0.845 & -3.157 & 0.034 \\
\hline BMSGR & 0.404 & 7.71434 & 2.715 & 0.175 & -0.636 & -1.648 & 0.175 \\
\hline MINTR & 0.909 & 2.69662 & 50.957 & 0.002 & -0.963 & -7.138 & 0.002 \\
\hline EXCHRF & 0.542 & 6.76348 & 4.736 & 0.095 & -0.736 & -2.176 & 0.095 \\
\hline UNEMR & 0.665 & 5.78189 & 7.954 & 0.048 & 0.816 & 2.820 & 0.048 \\
\hline
\end{tabular}

The results of the analysis concerning the evolution of the dependent variable under the influence of the regression factor and of the residual factor, calculated by means of the $F$ test, considering the high values of $\mathrm{F}$ in all the regression equation, as well as the Sig. value of F, lower than 0.05 in case of inflation rate, market interest rate and unemployment rate, reflects the fact that the connection between the respective variables and credit risk is significant, during the considered period. Also the test of the parameters in all regression equations using Student Test confirms, due to the Sig. value of $t$ which is lower than 0.05 for the same independent variables mentioned before, that there is a significant connection between them and the dependent variable. In other words, the value of $\beta$ line corresponds to a significant connection between the evolution of inflation rate, market interest rate and unemployment rate and the evolution of credit risk ratio during 2008-2013 in the Romanian banking sector. With a degree of confidence of $90.5 \%$ we can say that the exchange rate fluctuation also reflects a significant connection with the credit risk ratio.

Our regression analysis findings confirm the hypothesis according to which the money supply growth rate and the market foreign exchange rate are negatively related with credit risk and the unemployment rate is positively related with it (Table 4).

Table 4 Results of the testing research hypothesis

\begin{tabular}{|c|c|c|c|c|c|c|c|}
\hline \multirow{2}{*}{$\begin{array}{l}\text { INDEPENDENT } \\
\text { VARIABLE }\end{array}$} & \multirow[t]{2}{*}{ SYMBOL } & \multirow{2}{*}{$\begin{array}{l}\text { EXPECTED SIGN } \\
\text { (Hypothesis) }\end{array}$} & \multicolumn{2}{|c|}{$\begin{array}{c}\text { PEARSON } \\
\text { CORRELATION }\end{array}$} & \multicolumn{2}{|c|}{$\begin{array}{c}\text { REGRESSION } \\
\text { ANALYSIS }\end{array}$} & \multirow[t]{2}{*}{ RESULT } \\
\hline & & & $\mathrm{H}=0$ & $H \neq 0$ & $\mathrm{H}=0$ & $\mathrm{H} \neq 0$ & \\
\hline Real GDP growth rate & RGDPGR & - & $\mathbf{v}$ & $\mathbf{x}$ & $\mathbf{v}$ & $\mathrm{x}$ & Not significant \\
\hline Inflation rate & INFR & + & $\mathbf{x}$ & v & $\mathbf{x}$ & 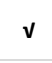 & $\begin{array}{c}\text { Significant and } \\
\text { negative }\end{array}$ \\
\hline $\begin{array}{l}\text { Broad money supply } \\
\text { growth rate }\end{array}$ & BMSGR & - & 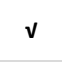 & $\mathbf{x}$ & $v$ & $x$ & $\begin{array}{c}\text { Significant and } \\
\text { negative }\end{array}$ \\
\hline Market interest rate & MINTR & + & $\mathrm{x}$ & $\mathbf{v}$ & $\mathrm{x}$ & $\checkmark$ & $\begin{array}{l}\text { Significant and } \\
\text { negative }\end{array}$ \\
\hline $\begin{array}{l}\text { Foreign exchange rate } \\
\text { fluctuation }\end{array}$ & EXCHRF & - & $v$ & $x$ & v & $x$ & $\begin{array}{c}\text { Significant and } \\
\text { negative }\end{array}$ \\
\hline Unemployment rate & UNEMR & + & v & $\mathbf{x}$ & v & $\mathbf{x}$ & $\begin{array}{l}\text { Significant and } \\
\text { positive }\end{array}$ \\
\hline
\end{tabular}

According to the results before, we performed a regression using as dependent variable the credit risk ratio and as independent variables exchange rate fluctuation and unemployment rate. The equation is:

$$
y=\alpha+\beta_{1} \cdot E X C H R F+\beta_{2} \cdot U N E M R+\varepsilon
$$


Table 5 Results of the regression analysis to test the influence of exchange rate and unemployment rate on credit risk ratio

\begin{tabular}{ccccccccc}
\hline & \multicolumn{3}{c}{ MODEL } & \multicolumn{2}{c}{ ANOVA } & \multicolumn{3}{c}{ COEFFICIENTS } \\
\cline { 2 - 8 } & $\begin{array}{c}\mathbf{R}^{2} \\
\text { (R Square) }\end{array}$ & $\begin{array}{c}\text { Std. Error } \\
\text { of the } \\
\text { Estimate }\end{array}$ & $\begin{array}{c}\text { Durbin- } \\
\text { Watson }\end{array}$ & F Test & $\begin{array}{c}\text { F Test } \\
\text { Significance } \\
\text { (Sig.) }\end{array}$ & $\begin{array}{c}\text { Beta } \\
\text { Coefficient } \\
(\boldsymbol{\beta})\end{array}$ & $\begin{array}{c}\text { T Test - } \\
\boldsymbol{\beta}\end{array}$ & $\begin{array}{c}\text { T Test } \\
\text { Significance } \\
\text { (Sig.) }\end{array}$ \\
\hline Equation (2) \\
$\begin{array}{c}\text { EXCHRF } \\
\text { UNEMR }\end{array}$ & 0.742 & 5.86399 & 1.007 & 4.311 & 0.131 & & & \\
\hline & & & & & -0.361 & -0.943 & 0.415 \\
\hline
\end{tabular}

Source: Own calculations based on the NBR and Eurostat available data

As we can observe, the results of the regression analysis to test the influence of EXCHR and UNEMR on CRR indicate a relatively meaningful relationship between variables $\left(\mathrm{R}^{2}=0.742\right)$, but with a degree of confidence of $87 \%$. The Durbin-Watson level of 1.007 suggests a positive serial correlation. According to the results for the independent variables, we can say that as foreign exchange rate fluctuation increases (the national currency appreciates) the credit risk diminishes, while an increased unemployment rate will increase the credit risk.

\section{Conclusions}

Many studies focus their attention on the issue of the loan portfolio quality, especially over the last years, in the context of the turmoil in international financial market caused by the global crisis.

Based on the aggregate available data on National Bank of Romania and Eurostat, this paper explore the interactions between macroeconomic conditions, such as: real GDP growth rate, inflation rate, market interest rate, broad money supply, foreign exchange rate fluctuation and unemployment rate, and credit risk in Romanian banking sector during 2008-2013.

Due to the interrelations of indicators' complexity, a multidimensional statistical analysis was performed in order to find a relation between the macroeconomic conditions and the credit risk ratio. Our regression analysis findings confirm the hypothesis according to which the money supply growth rate and the market foreign exchange rate are negatively related with credit risk and the unemployment rate is positively related with it. Furthermore, our findings revealed that the credit risk is significantly and negatively affected by the exchange rate fluctuation and significantly and positively affected by the unemployment rate. However, our research does not indicate a significant relationship between credit risk ratio and real GDP growth rate.

\section{References}

Agnello, L., Furceri, D. et al (2011), Fiscal Policy Discretion, Private Spending and Crisis Episodes, NIPE Working Papers, 31, University of Minho.

Ahmad, N. H. (2003), Formation credit risk, regulatory price effect and the path linking credit to total risk, University Utara Malaysia.

Ahmad, N. H., Ariff, M. (2007), Multi-country study of bank credit risk determinants, The International Journal of Banking and Finance, 5 (1), 135-152.

Ali, A., Daly, K. (2010), Macroeconomic determinants of credit risk: Recent evidence from a cross country study, International Review of Financial Analysis, 19 (3), $165-171$. 
Athanasoglou, P. P., Brissimis, S. N. et al (2008), Bank-specific, industry-specific and macroeconomic determinants of bank profitability, Journal of International Financial Markets, Institutions and Money, 18 (2), 121-136.

Aver, B. (2008), An empirical analysis of credit risk factors of the Slovenian banking system, Managing Global Transitions, 6 (3), 317-334.

Bairamli, N., Kostoglou, V. (2010), The Role of Savings in the Economic Development of the Republic of Azerbaijan, International Journal of Economic Sciences and Applied Research, 3 (2), 99-110.

Barseghyan, L. (2010), Non-Performing Loans, Prospective Bailouts and Japan's Slowdown, Journal of Monetary Economics, 57 (7), 873-890.

Berk, J. M., Bikker, J. A. (1995), International interdependence of business cycle in manufacturing industry: the use of leading indicators for analysis and forecasting, Journal of Forecasting, 14, 1-23.

Bofondi, M., Ropele, T. (2011), Macroeconomic determinants of bad loans: evidence from Italian banks, Bank of Italy Occasional Paper, 89.

Bucur, I. A. (2013), On the Economic Development of Romania as a Member of E.U. in the Frame of the Global Economic Crisis, Ovidius University Annals Economic Sciences Series, 13 (1), 152-157.

Castro, V. (2013), Macroeconomic determinants of the credit risk in the banking system: the case of the GIPSI, Economic Modeling, 31, 672-683.

Das, A., Ghosh, S. (2007), Determinants of Credit Risk in Indian State-owned Banks: An Empirical Investigation, Economic Issues-Stoke on Trent, 12 (2), 27-46.

Demirguc-Kunt, A., Detragiache, E. (1998), The determinants of banking crises in developing and developed countries, Staff Papers-International Monetary Fund, 45 (1), 81-109.

Fainstein, G., Novikov, I. (2011), The role of macroeconomic determinants in credit risk measurement in transition country: Estonian example, International Journal of Transitions and Innovation Systems, 1 (2), 117-137.

Fofack, H. (2005), Nonperforming loans in Sub-Saharan Africa: Causal analysis and macroeconomic implications, Working Paper Series, 3769.

Gambera, M. (2000), Simple forecasts of bank loan in the business cycle, Emerging Issues Series, 3, 1-27.

Gonzales-Hermosillo, B. (1999), Developing Indicators to Provide Early Warnings of Banking Crises, Finance \& Development, 36, 36-39.

de Guimaraes e Souza, G. J., Feijo, C. A. (2011), Credit risk and macroeconomic interactions: empirical evidence from Brazilian Banking System, Modern Economy, 2, 910-929.

Gunsel, N. (2012), Micro and Macro determinants of bank fragility in North Cyprus economy, African Journal of Business Management, 3 (6), 1323-1329.

Gup, B. E., Kolari, J. W. (2005), Commercial Banking: The Management of Risk, 3rd Edition, John Wiley and Sons Ltd, Australia.

Hardy, D., Pazarbasioglu, C. (1998), Leading indicators of banking crisis: was Asia different?, IMF Working Paper, 91, 1-32.

Jimenez, G., Saurina, J. (2006), Credit cycles, credit risk, and prudential regulation, International Journal of Central Banking, 2 (2), 65-98.

Kalirai, H., Scheicher, M. (2002), Macroeconomic stress testing: preliminary evidence for Austria, Financial Stability Report, 3, 58-74.

Kroszner, R. S., Luc, L., Klingebiel, D. (2007), Banking crises, financial dependence and growth, Journal of Financial Economics, 87, 187-228.

Kristo, S. (2013), Eficiency of the Albanian banking system: Traditional approach and Stochastic Frontier Analysis, International Journal of Economic Sciences and Applied Research, 6 (3), 61-78. 
Llewellyn, D. T. (2002), An analysis of the causes of recent banking crises, The European Journal of Finance, 8 (2), 152-175.

Louzis, D. P., Vouldis, A. T., Metaxas, V. L. (2012), Macroeconomic and bankspecific determinants of non-performing loans in Greece: a comparative study of mortgage, business and consumer loan portfolios, Journal of Banking \& Finance, 36, 1012-1027.

Mileris, R. (2012), The effects of macroeconomic conditions on loan portfolio credit risk and banking system interest income, Ekonomika, 91 (3), 85-100.

National Bank of Romania (2009-2013), Annual Reports.

National Bank of Romania (2008), Regulation 11/2008, amending and supplementing NBR Regulation No. 3/2007 regarding limiting credit risk on loans to individuals.

Ngerebo, T. A. (2011), The impact of foreign exchange fluctuation on the intermediation of banks in Nigeria (1970-2004), African Journal of Business Management, 6 (11), 3872-3879.

Nikolaidou, E.,Vogiazas, S. D. (2013), Credit Risk in the Romanian Banking System: Evidence from an ARDL Model, Balkan and Eastern European Countries in the Midst of the Global Economic Crisis Contributions to Economics, Springer Editions, 87-101.

Nkusu, M. (2011), Nonperforming loans and macro financial vulnerabilities in advanced economies, IMF Working Papers, 1-27.

Poudel, R. P. S. (2013), Macroeconomic determinants of credit risk in Nepalese banking industry, Proceedings of 21st International Business Research Conference.

Quagliariello, M. (2007), Banks' riskiness over the business cycle: a panel analysis on Italian intermediaries, Applied Financial Economics, 17 (2), 119-138.

Rajaraman, I., Vasishtha, G. (2002), Non-Performing Loans of PSU Banks: Some Panel Results, Economic and Political Weekly, 37 (5), 429-435.

Rinaldi, L., Sanchis-Arellano, A. (2006), Household debt sustainability: What explains household non-performing loans? An empirical analysis, ECB Working Paper, 570.

Salas, V., Saurina, J. (2002), Credit risk in two institutional regimes: Spanish commercial and savings banks, Journal of Financial Services Research, 22 (3), 203-224.

Samad, A. (2012), Credit Risk Determinants of Bank Failure: Evidence from US Bank Failure, International Business Research, 5 (9), 10-15.

Santomero, A. (1997), Commercial bank risk management: an analysis of the process, Journal of Financial Services Research, 12 (2), 83-115.

Shu, C. (2002), The impact of macroeconomic environment on the asset quality of Hong Kong's banking sector, R. D. Economic Research Division, Hong Kong Monetary Authority.

Sinkey, J. F., Greenawalt, M. B. (1991), Loan-loss experience and risk-taking behavior at large commercial banks, Journal of Financial Services Research, 5, 43-59.

Solomon, D. C., Muntean, M. (2012), Assessment of Financial Risk in Firm's Profitability Analysis, Economy, Transdisciplinarity, Cognition, 15 (2), 58-67.

Thiagarajan, S., Auuapan, S. et al (2011), Credit risk determinants of public and private sector banks in India, European Journal of Economics, Finance and Administrative Science, 34, 147-154.

Valahzaghard, M. K., Kashefi, M., Alikhani, A., Hosseini, S. E. (2012), The effect of macroeconomic factors on credit risk in the banking system of Iran, Management Science Letters, 2, 1747-1754. 
Vogiazas, S. D., Nikolaidou, E. (2011), Credit risk determinants in the Bulgarian banking system and the Greek twin crises, MIBES, South East European Research Centre, 177-189.

Vogiazas, S. D., Nikolaidou, E. (2011), Investigating the determinants of nonperforming loans in the Romanian Banking System: An empirical study with reference to the Greek crisis, Economics Research International.

Zameer, S., Siddiqi, M. W. (2010), The impact of Export, FDI and External Debt on Exchange Rate Volatility in Pakistan, International Journal of Contemporary Research in Business, 2 (7), 337-354.

Zeng, S. (2011), Bank Non-Performing Loans (NPLS): A Dynamic Model and Analysis in China, Modern Economy, 2, 100-110.

Zribi, N., Boujelbene, Y. (2011), The factors influencing bank credit risk: The case of Tunisia, Journal of Accounting and Taxation, 3 (4), 70-78. 